\title{
Epidemiology and the City: Communal vs. Intercommunal Health Policy-Making in Jerusalem from the Ottomans to the Mandate, 1908-1925
}

\author{
Philippe Bourmaud
}

The nineteenth century shaped an image of Jerusalem as an unhealthy city. Sanitary imagination, that is, the growing sense of disease as a hidden threat and the parallel picturing and popularization of what a healthy environment should be, encouraged the multiplication of community-based health institutions from the 1840 s onwards. ${ }^{1}$ Yet, these institutions fell short of forming a healthcare system, or of satisfying early twentieth-century public health activists promoting a needs-based approach to healthcare. ${ }^{2}$

Social and political change, not least the intensification of Jewish immigration, were the cause of these failures. By the first decade of the twentieth century, meeting the main medical needs of Jewish immigrants had become a major concern for the Zionist movement. The Young Turks were also concerned with the systematization of access to services, the lack of which had been made evident by the development of the empire's statistical apparatus. ${ }^{3}$ Just after World War I, connections between the various medical institutions in Jerusalem boosted public health research, nurturing hopes for the rationalization of a balkanized health sector, not through institutional integration, but through the identification of shared priorities. The number and scope of medical institutions in Jerusalem expanded rapidly, leading Jurji Zaydan, a medical student and the founder of the Egypt-based Al-Hilal newspaper, to note in

1 Yaron Perry and Efraim Lev, Modern Medicine in the Holy Land: Pioneering British Medical Services in Late Ottoman Palestine (London: I. B. Tauris, 2007); Norbert Schwake, Die Entwicklung des Krankenhauswesens der Stadt Jerusalem vom Ende des 18. bis zum Beginn des 20. Jahrhunderts, 2 vols. (Herzogenrath: Murken-Altrogge, 1983).

2 Marc-Olivier Desplaudes, "Une fiction d'institution: les 'besoins de santé de la population," in Comment se construisent les problèmes de santé publique, ed. Claude Gilbert and Emmanuel Henry (Paris: La Découverte, 2009).

3 Kemal H. Karpat, "The Ottoman Adoption of Statistics from the West in the 19th Century," in Studies on Ottoman Social and Political History: Selected Articles and Essays, ed. Kemal H. Karpat (Leiden: Brill, 2002), 132-45. 
1914 that Palestine offered the largest scope in sanitary services, and that the greatest concentration of health institutions in the Levant could be found in Jerusalem. ${ }^{4}$ And yet, the first years of the Mandate saw the organization of a dual healthcare system, split between a self-financed body of Zionist institutions on the one hand, and government and voluntary institutions under government supervision on the other.

Marcella Simoni and Sandy Sufian have shown that the Mandate, rather than fostering intercommunal cooperation, led the divergence of public health priorities between Jews and Arabs (Christians, in spite of the presence of many Christian medical missionary institutions aimed at catering to their health needs, and especially Muslims) to become major discrepancies in healthcare provision. ${ }^{5}$ This chapter questions the procedures and debates surrounding the setting of health policy priorities. It argues that the growth of late-Ottoman Jerusalem entailed a shift from communal to intercommunal definitions of health needs, initiating enquiries in the city and its surroundings. Establishing public health priorities required a capacity to process morbidity and mortality in a statistical fashion, which was a daunting task in late Ottoman Jerusalem. The Mandate developed an apparatus to deal with the task on the scale of the new territory of Palestine. A turning point, in 1923, was the debate about healthcare priorities between the Hadassah Medical Organization (HMO), the main Zionist medical organization in the early years of British occupation, ${ }^{6}$ its main funder, the American Jewish Joint Distribution Committee (AJDC), and British authorities. Rather than erasing community differences, health policy debates followed a late colonial pattern of decision-making where Westerners, endowed with money and expertise, had the upper hand, but had to propagandize the Arab population into adhering to the new public health priorities.

4 Jurji Zaydan, "Filastin" [Palestine], in Mu'allafat Jurji Zaydan al-kamilah [The complete works of Jurji Zaydan], 21 vols. (Beirut: Dar al-Jil, 1982), vol. 19, 542-43.

5 Marcella Simoni, A Healthy Nation: Zionist Health Policies in British Palestine (1930-1939) (Venice: Cafoscarina, 2010); Sandra M. Sufian, "Healing Jerusalem: Colonial Medicine and Arab Health from World War I to 1948," in Jerusalem Interrupted: Modernity and Colonial Transformation, 1917-present, ed. Lena Jayyusi (Northampton: Olive Branch Press, 2015).

6 Shifra Shvarts and Theodore M. Brown, "Kupat Holim, Dr. Isaac Max Rubinow, and the American Zionist Medical Unit's Experiment to Establish Health Care Services in Palestine, 1918-1923," Bulletin of the History of Medicine 72, no. 1 (1998). 


\section{Documenting Sanitary Change from the Ottoman to the Mandatory Period}

The material for a social history of Ottoman and Mandatory urban health policy making is in abundant, albeit uneven supply. This is partially due to a number of health-related series in the Ottoman Archives of the Prime Minister's Office (Başbakanlık Osmanlı Arşivi), which until very recently were unavailable. Still, data can be derived from other series: the HR.iD (Hariciye Nezâreti İdare, Ministry of Foreign Affairs fond) subseries sheds light on the foreign healthcare institutions in Jerusalem, ${ }^{7}$ offering an Ottoman counterpoint to the powers protecting those medical activities. ${ }^{8}$

The Jerusalem Municipal Archives, located in the municipal compound in West Jerusalem, present an array of documents. These documents deal not only with premunicipality local powers and municipal policy from the $1860 \mathrm{~s}$ onwards ${ }^{9}$ but also with charities and humanitarian foundations since the nineteenth century. ${ }^{10}$ The archives of the Department of Health of the British government of Palestine following the occupation of the country are split for the most part between the UK National Archives in London ${ }^{11}$ and the Israel State Archives in Jerusalem. ${ }^{12}$

7 Ottoman State Archives (BOA), HR.ì, gömlek 1550, dosya 11-64 (1875-1908); gömlek 1551, dosya 1 to 27 (1909-1917); gömlek 1793, dosya 16-31 (1912-14); gömlek 1794, dosya 1-6 (1908-10); gömlek 1803, dosya 63-68 (1912-13); gömlek 1812, dosya 22-28 (1911) and 41-50 (1902); gömlek 1813, dosya 1-6o (1904-17); gömlek 2022, dosya 81-84 and 93 (1904-6); gömlek 2038, dosya 24 (1908).

8 As regards French diplomatic archives, see Nantes Diplomatic Archives Centre (CADN), Jerusalem Consulate (hereafter Jerusalem), ser. A, files 103-108 (1850-1914).

9 See Yasemin Avc1, Vincent Lemire, and Falestin Naili, "Publishing Jerusalem's Ottoman Municipal Archives (1892-1917): A Turning Point for the City's Historiography," Jerusalem Quarterly, no. 60 (2014). On municipal healthcare institutions and the municipal hospital during the mandate, see Jerusalem Municipal Archives (JMA) 180 (1922-56).

10 JMA 284 (1895-1920s), 310 (1910-48), 392 (1910-49), 1649 (1879-1994), 2581 (1918-94), 2680 (1883-1914, 1978), $2682(1844-1896)$ and $2686(1890-1965)$.

11 These include the records of the nineteenth- and early twentieth-century British consulate in Jerusalem, established in 1841: The National Archives of the UK (TNA): Foreign Office (FO), 195 (1841-1914). The archives of the Mandatory Department of Health are dispersed through the subseries of the Colonial Office ( $\mathrm{CO}$ ) papers on Palestine: TNA: co 733 (1918-48).

12 Of interest for this chapter: Israel State Archives (ISA), files M/6/6561 (1922-23) and $\mathrm{M} / 20 / 6561$ (1922-23). 
Non-state actors were actively involved in the development of the healthcare system in Jerusalem. The Central Zionist Archives in Jerusalem host an array of documentation on various organizations for the colonization of Palestine, ${ }^{13}$ early Zionist parties such as the Lovers of Zion ${ }^{14}$ and on the Zionist Executive during the Mandate. ${ }^{15}$ Among research on precolonial medical endeavors, Stefan Wulf has written the history of the Mühlens sanitary mission to Jerusalem. His work is based on state archives in Berlin and institutional archives in Hamburg. ${ }^{16}$

Coming into prominence just before and after World War I, global American foundations took an interest in Jerusalem. The Rockefeller Archives Center in Tarrytown, New York, holds files documenting the close relationships between the International Health Board, funded by the Rockefeller Foundation, and the Zionist Executive in the antimalaria campaign in Palestine, ${ }^{17}$ as well as the foundation's connection with the AJDC, involved in the distribution of relief to Jews at the close of the Great War and the funding of the Hм0. ${ }^{18}$ These files shed light on the debates over health priorities and healthcare organization at the start of the Mandate.

\section{Nineteenth-Century Jerusalem: A Communal Approach to Health Hazards and Infectious Diseases}

\section{Healthcare in Jerusalem: Ottoman Reforms and Foreign Clientele}

The development of healthcare institutions over the nineteenth century was part of the larger movement to create modern institutions across the Ottoman Empire. It aimed at providing every province with public services

\footnotetext{
13 See Central Zionist Archives (CZA), J15: Palestine Jewish Colonization Association; J113: Hadassah Medical Organization (1918-77).

14 See CZA/A31: Personal papers of Dr. Hillel Jaffe (1864-1935).

15 Of particular interest are the record groups CZA/S28: Committee for the Care of Sufferers from Chronic Diseases (1924-27); L53: Health Council (1922-28).

16 See Stefan Wulf, Jerusalem - Aleppo - Konstantinopel: Der Hamburger Tropenmediziner Peter Mühlens im Osmanischen Reich am Vorabend und zu Beginn des Ersten Weltkriegs (Münster: LIT, 2005); Stefan Wulf, Das Hamburger Tropeninstitut 1919 bis 1945: Auswärtige Kulturpolitik und Kolonialrevisionismus nach Versailles (Berlin: Dietrich Reimer, 1994).

17 Rockefeller Archives Center, Tarrytown, NY (RAC), Rockefeller Foundation Records (RF), Photographs, FAoo3, box 170, ser. 825 I (1924-25); Record Group (RG) 5, International Health Board (Інв)/D, FA115, ser. 2, box 61 (1918-25).

18 RAC, RF, Alfred E. Cohn Papers, Rockefeller University records, FA 802, box 18 (1921-51).
} 
such as hygiene control and municipal physicians. ${ }^{19}$ Until the 1840 s, institutional healthcare was available from specialized private practitioners involved in various trades and was organized on a denominational basis. The one hospital or bimaristan, based on a Muslim religious foundation or waqf, the bimaristan al-salahi, presumably established by Saladin in the late twelfth century, remained active until the early $1850 s .{ }^{20}$ Houses provided to lepers outside the city walls were said to be based on another Muslim waqf established in the sixteenth century. ${ }^{21}$ Outside the framework of waqf foundations, convents kept pharmacies, first and foremost for their own communities. In the early nineteenth century, the most important of these was the pharmacy of the Franciscan convent. ${ }^{22}$ However, over the second half of the nineteenth century, the bulk of Jerusalemite healthcare institutions were western-backed Jewish and Christian institutions. What purpose did these serve? They cannot be accounted for by the Foucauldian concept of discipline as in European hospitals, where the interiorization of such procedures as hospital rules was a way to render populations productive, ${ }^{23}$ nor by the understanding of Western medicine in Jerusalem as a "tool of empire,"24 working in sanitary enclaves alongside

19 Jens Hanssen, Fin de Siècle Beirut: The Making of an Ottoman Provincial Capital (Oxford: Oxford University Press, 2005), 115-37; Malek Sharif, Imperial Norms and Local Realities: The Ottoman Municipal Laws and the Municipality of Beirut (1860-1908) (Beirut: OrientInstitut; Würzburg: Ergon, 2014), 181-208.

20 Kamil al-Asali, Muqaddima fi tarikh al-tibb fi-l-Quds mundhu aqdam al-azminah hata sanat 1918 miladi [Introduction to the history of medicine in Jerusalem from ancient times until 1918] (Amman: Jordanian University, 1994), 165; Musa Sroor, Fondations pieuses en mouvement: De la transformation du statut de propriété des biens waqfs à Jérusalem (Aix-en-Provence: Institut de recherches et d'études sur le monde arabe et musulman (Iremam); Damascus, Beirut: Institut français du Proche-Orient (Ifpo), 2010), 177-78.

21 Henry Vandyke Carter, Reports on Leprosy (Second Series), comprising notices of the disease as it now exists in North Italy, the Greek Archipelago, Palestine and parts of the Bombay Presidency of India (London: Eyre and Spottiswoode, 1876), 14-15. The author goes on to quote British consul Moore that the waqf had been established by "a lady" and had remained active "[since] the time of Selim Sultan," referring to either the last years of Selim I's reign after the conquest of Jerusalem $(1517-20)$ or to the time of Selim II (156674), following the trend of evergetism in the Holy City during his father Süleyman's reign.

22 Schwake, Die Entwicklung, vol. 1, 91-92.

23 Michel Foucault, "L'incorporation de l'hôpital dans la technologie moderne," Hermès, La Revue 2, no. 2 (1988).

24 Roy MacLeod, "Preface," in Disease, Medicine, and Empire: Perspectives on Western Medicine and the Experience of European Expansion, ed. Roy MacLeod and Milton Lewis (London: Routledge, 1988). 
largely untouched surroundings ${ }^{25}$ or through sanitary control of colonial populations. In the long run, Jerusalem's hospitals and dispensaries were inspired by anticipations of colonial opportunities. Still, they were often founded and expanded at the request of local non-Muslim communities protected by European countries, whose rivalries afforded the former with leverage. ${ }^{26}$ Ottoman and foreign voluntary institutions were contrasting answers to popular demands.

Ottoman health policies focused on objective health needs in keeping with the agenda of Ottoman reforms, which called for territorial and communal equality of access to state services. The Jerusalem municipality enforced hygienic measures such as street cleaning and controlling slaughterhouses. Admission to the municipal hospital of Jerusalem, founded in 1891, was conditional on the payment of a flat-rate fee of one mecidiye, the late Ottoman currency. ${ }^{27}$ Recruitment was intercommunal: Greeks and Jews were hired as physicians, ${ }^{28}$ and Catholic women's orders, such as the Daughters of Charity, were used as nursing staff. ${ }^{29}$ The limits of this egalitarian spirit are embodied in the fact that healthcare was gendered. The Ottoman state tried to channel women into a formal training in midwifery and nursing, but with limited success, largely on account of the centralization of education in these professions in Istanbul. By contrast, it did not want them to go into the medical profession and ended up officially forbidding their practice as physicians. ${ }^{30}$

European institutions, on the other hand, were works of beneficence. They were inspired by a sanitary imagination and catered to a specific religious community rather than health needs. Earlier institutions, such as the pharmacy of the Franciscan convent, had partly been motivated by the needs of the Christian pilgrims who came to Jerusalem for the Easter celebrations. This function was increasingly incorporated into the missions of the Western-style hospitals as

25 David Arnold, Colonizing the Body: Epidemic Disease and State Medicine in Nineteenth Century India (Berkeley: University of California Press, 1993).

26 Philippe Bourmaud, "Les entrelacs du public et du privé dans le monde ottoman," in Espace et construction de soi, ed. Maria Uzcategui and Yves Moreau, special issue of Les Carnets du LARHRA 3, no. 2 (2014).

27 Sufian, "Healing Jerusalem," 116, 118.

28 Schwake, Die Entwicklung, vol. 2, 518; Tawfik B. Canaan, "Cerebro-Spinal Meningitis in Jerusalem," Al-Kulliyeh 2, no. 6 (1911).

29 Philippe Bourmaud, "Ya Doktor! Devenir médecin et exercer son art en "Terre sainte," une expérience du pluralisme médical dans l'Empire ottoman finissant (1871-1918)" (PhD diss., University of Provence, 2007), 714.

$30 \quad$ Ibid., 192. 
Christian pilgrims grew in number in the later part of the nineteenth century. In times of epidemics, these movements of pilgrims could be a subject of sanitary concern, yet not as much as the more numerous and scattered gathering of Muslim pilgrims to Mecca, who were accused of spreading cholera to Europe in 1865 , but whose route circumvented Jerusalem. ${ }^{31}$ Descriptions of Jerusalem in the nineteenth and early twentieth centuries dwelled on the city as a site of multiple sanitary hazards: garbage strewn on open fields, dark, narrow alleys, and the use of cisterns filled with stagnant waters accounted for morbidity in the city. ${ }^{32}$ The image was not pure imagination: poor sanitary conditions fueled the long-standing debate on modernizing the water supply of the city.33 Urban residents themselves were sensitive to the lack of hygiene, ${ }^{34}$ but it was the place Jerusalem held in the Western imagination that drew massive investments into healthcare in the city.

European hospitals and dispensaries were protected by a set of capitulations and treaties securing European institutions, Europeans subjects and certain non-Muslim Ottoman subjects against possible inequities under Islamic law. ${ }^{35}$ In practice, the capitulations barred Ottoman officials from inspecting the work of foreign institutions, an object of resentment for public health activists advocating needs-based health policies. ${ }^{36}$ Even after the abolition of the capitulations in 1914, and the British occupation, this state of affairs lingered:

The capitulations, in the days of the Turks, were the best of help for foreigners. They could do whatever they wanted in their castle and their

31 Sylvia Chiffoleau, Genèse de la santé publique internationale: De la peste d'Orient à l'O.M.S. (Beirut; Institut français du Proche-Orient; Rennes: Presses Universitaires de Rennes, 2012), 83-96.

32 Yehoshua Ben-Arieh, Jerusalem in the Nineteenth Century, vol. 1, The Old City (Jerusalem: Yad Ben-Zvi Institute, 1984), chap. 5 .

33 Vincent Lemire, La soif de Jérusalem: essai d'hydrohistoire, 1840-1948 (Paris: Publications de la Sorbonne, 2011).

34 See for instance, on World War I: Ihsan Turjman, 'Am al-jarad, Al-harb al-'uthma wa mahu al-madi al-uthmani fi Filastin [The year of the locust: the Great War and the fading of the Ottoman past in Palestine], ed. Salim Tamari (Beirut: Institute for Palestine Studies, 2008), 201.

35 John Edward Wansbrough et al., "Imtiyazat," in The Encyclopedia of Islam, ed. Hamilton Alexander Rosskeen Gibb (Leiden: Brill, 1986), 1178-225.

${ }_{3} 6$ Philippe Bourmaud, "Public Space and Private Spheres: The Foundation of St Luke's Hospital of Nablus by the CMS (1891-1901)," in New Faiths in Ancient Lands: Western Missions in the Middle East in the Nineteenth and Early Twentieth Century, ed. Heleen L. Murre-van den Berg (Leiden: Brill, 2006), 151-74. 
institutions, without interference or witness. There was no sanitary inspection of their hospitals, their asylums and their schools ... This was because when it came to charities, the owners thought that what they were giving was a divine favour, while they would not have borne the cost of bringing these institutions up to level. ${ }^{37}$

The capitulation system also made it harder to decipher public health priorities.

\section{Communal Patterns of Health Information and Public Health Priorities}

Public health priorities in Jerusalem evolved through the nineteenth and early twentieth centuries from a focus on epidemic diseases to a larger array of pathologies. Malaria and trachoma were given prominence, ${ }^{38}$ but studies started to show the prevalence of so-called infantile diseases (measles, German measles, mumps, etc.). ${ }^{39}$ Yet Ottoman health policy, under pressure from European states, ${ }^{40}$ still focused on the virulent epidemics liable to spread to Europe such as plague and cholera, and neglected other diseases, which in the long run killed many more. ${ }^{41}$

Redefining health policy was a difficult task owing to the lack of reliable data. Intracommunal data on epidemics had long been deemed more reliable than official figures. ${ }^{42}$ Moreover, foreign institutions under the capitulations shrouded their work in secrecy: Estelle Blyth, the daughter of the first Anglican bishop of Jerusalem, noted after the British occupation that in Ottoman times, "statistics of all kinds, whether Turkish or foreign, were jealously guarded by those in authority, and were exceedingly hard to get at." 43 Communal divisions hindered epidemiological analysis.

"Kitab maftuh ila da'irat al-sihhah" [Open letter to the Department of Health], Mir'at al-Sharq, 47, August 18, 1920, 1-2.

38 Edward W. G. Masterman, "Jerusalem from the Point of View of Health and Disease," Lancet 191, no. 4930 (1918); Anat Mooreville, "Oculists in the Orient: A History of Trachoma, Zionism and Global Health, 1882-1973" (PhD diss., University of California, Los Angeles, 2015).

39 Canaan, "Cerebro-Spinal Meningitis."

40 Chiffoleau, Genèse de la Santé publique internationale, 187-219.

41 Masterman, "Jerusalem from the Point of View," 305.

42 See, for instance, the Diplomatic Archive Center of the Ministry of Foreign and European Affairs, La Courneuve (MAE), Correspondance Consulaire et Commerciale (CCC), Jerusalem, RG 3, Laffon to the Foreign Minister, Jerusalem, December 12, 1865.

Estelle Blyth, When We Lived in Jerusalem (London: John Murray, 1927), 105. 


\section{Zionist Colonization Priorities}

As a colonization movement, Zionism had a vested interest in well-guided public health. Zionist rural colonies were located close to marshes where anopheles, the malaria vector, could breed easily and settlers soon became conscious of their particular vulnerability to the disease. ${ }^{44}$ Zionist expertise on malaria was therefore primarily rural, but given that most of Palestine's Jewish population was urban, malaria also influenced Zionist perceptions of urban planning. ${ }^{45}$ It was also among the workers' unions in the rural colonies that the first "sick funds" (Kupat Holim) were founded, which would later become the main financial resource of Zionist healthcare. ${ }^{46}$

In an intercommunal setting such as Jerusalem, Zionist physicians and their financial experts recognized the importance of moving away from the communal approach to healthcare, ${ }^{47}$ but they prioritized the issues that affected immigrants most, such as malaria. The restoration of the Ottoman constitution in 1908, vindicated the needs-based approach of Zionist physicians, but also moved away from the communal framework of health data.

\section{The New Ottoman Political Order: Publicizing “Objective” Public Health Problems}

\section{Common Good in the Age of Statistics}

The restoration of the constitution changed policy making in the Ottoman Empire, allowing public policy to be openly criticized. Official indifference was invoked to account for growing sanitary threats such as tuberculosis:

[Those] whom I blame are the venerable members of our municipality, who pass before those places everyday, and who are educated. They ... close their eyes to those public places that are falling apart and, much like poisoned marshes, ... mar their physical as well as mental health.

44 Sufian, "Healing Jerusalem," 103.

45 Derek J. Penslar, Zionism and Technocracy: The Engineering of Jewish Settlement in Palestine, 1870-1918 (Bloomington: Indiana University Press, 1991), 18; CADN, A, 137: Herthetély, "Notes sur Bersasba," October 20, 1900.

46 On the early growth of collective Zionist health organizations, see Shifra Shvarts, The Workers' Health Fund in Eretz Israel Kupat Holim, 1911-1937 (Rochester: University of Rochester Press, 2002).

47 Erica B. Simmons, Hadassah and the Zionist Project (Lanham: Rowman \& Littlefield, 2005), 55 . 
All that our funds for public gardens have produced is a dry and narrow minigarden, surrounded by dust; there would be no harm in being more generous and giving an ample and clear garden, planted with pines, away from the dust, ... where special areas would be reserved for various sports. ${ }^{48}$

A public-minded generation was coming of age among Jewish immigrants as well as educated Arabs. ${ }^{49}$ Dealing with public problems through the lens of statistics was a way to rationalize political decisions in the name of the common good. This view was shared by the new authorities: the restoration of the constitution brought to power the Young Turk movement, whose leaders and intellectuals were under the influences of Émile Durkheim and Frédéric Le Play, two French sociologists who were active proponents of social statistics. ${ }^{50}$ For all the national and religious rivalries in Jerusalem, this idea made its way into the city's medical milieu.

\section{Intercommunal Data Exchange and Connected Networks}

In the years leading up to the war, official, missionary and Zionist health professionals converged around the clinical and statistical study of the city's health needs. The main manifestation of that trend was the organization, by the German colonial milieu, of a sanitary mission to Jerusalem from 1912 to 1914. Its head, Professor Peter Mühlens, a specialist in tropical medicine and malaria at the Institute for Maritime and Tropical Diseases in Hamburg, had soon screened the children "in most of the Moham.[medan], Jewish and Christian schools." ${ }^{11}$ Between their arrival and October 1913, over eighteen thousand blood samples were tested for malaria..52 In 1913, Mühlens established the International Sanitary Administration of Jerusalem, which set out to map disease, not only in the city, but in Palestine at large. It united the Jewish Health Bureau, a bacteriological institute founded by American Zionist philanthropist

48 Elias Halabi, "Al-Sill fi-l-Quds wa asbab intisharihi fiha" [Tuberculosis in Jerusalem and the causes for its diffusion], Filastin 60 (August 16, 1911).

Simmons, Hadassah, 38-39; Philippe Bourmaud, “'A Son of the Country.' Dr Tawfiq Canaan, Modernist Physician and Palestinian Ethnographer," in Struggle and Survival in Palestine/Israel, ed. Mark LeVine and Gershon Shafir (Berkeley: University of California Press, 2012).

5o Uriel Heyd, Foundations of Turkish Nationalism: The Life and Teachings of Ziya Gökalp (Westport: Hyperion Press, 1979).

$5^{1}$ BOA, HR.ID 1515/7, report by Mühlens, Jerusalem, February 1, 1914.

52 BOA, HR.ì 1515/7, "Discours du Professeur Mühlens, Directeur de l'Institut international d'Hygiène à Jérusalem, le 23 octobre 1913." 
Nathan Straus, the Pasteur Institute of Jerusalem and its antirabies work ${ }^{53}$ and various German and local physicians fighting tuberculosis and promoting social medicine. ${ }^{54}$ Although members of the Mühlens mission considered racial differences to be a founding principle of public health, ${ }^{55}$ the recruitment of the Administration was intercommunal, as were the populations under its study.

This raises the question of the colonial dimension of Mühlens's work. The German mission was sent by the main German institution for colonial medicine, but unlike similar contemporary missions, it included physicians of other nationalities and indigenous specialists. This was partly due to the precedent of Zionist efforts to map public health. Yet the Mühlens mission benefited from growing connections within the medical milieu of Jerusalem. In 1910, an epidemic of cerebro-spinal meningitis, a disease whose ambiguous symptoms had long been misdiagnosed by the city's clinicians, brought together practitioners from various hospitals around the German physician of the Sha'are Tsedek Jewish hospital, Dr. Moritz Wallach, and Dr. Tawfik Canaan. ${ }^{56}$

More than by bacteriology, the identification of the epidemic was made possible by the networks at the intersection of which stood the authors of the study and in particular, in the words of Mühlens, "our indefatigable collaborator, Dr. Canaan." ${ }^{57}$ A German cross-denominational connection had linked Canaan and Wallach, as well as Dr. Grussendorf, head physician of the German Lutheran hospital of the Kaiserwerth deaconesses of Jerusalem. Canaan had temporarily replaced Wallach at Shaare Tsedek during 1910. This German connection later facilitated Canaan's inclusion in the work of the Mühlens mission. A second connection was educational and generational: it tied Canaan and his colleague and former fellow student at the Syrian Protestant College (SPC), Dr. Albert Abu-Chédid, a Jewish physician of Algerian origin working at the Ottoman municipal hospital of the city. ${ }^{58}$ Lastly, Canaan, as a Protestant and an English speaker, had ties with English Protestant missionaries, possibly through the local branch of the Young Men's Christian Association, many of whose members were former SPC students, ${ }^{59}$ and through the college's

53 "Nachrichten aus dem Hl. Lande," Das Heilige Land, no. 2 (April 1913).

54 Wulf, Jerusalem - Aleppo - Konstantinopel, 50-53, 69-70.

55 Ibid., $54-55$.

56 Canaan, "Cerebro-spinal meningitis."

57 BOA, HR.İ 1515/7, "Discours du Professeur Mühlens, Directeur de l'Institut international d'Hygiène à Jérusalem, le 23 octobre 1913."

$5^{8}$ Bourmaud, "A Son of the Country,'” 104-24.

59 “Athletic Notes. The Jerusalem Football Series," Al-Kulliyeh 5, no. 6 (1914): 195-98. 
Jerusalem alumni association. ${ }^{60}$ Jerusalem's situation as a medical hub in the Middle East by 1914 was boosted by the habitus of SPC alumni, who were encouraged to cultivate connections and use their expertise to promote social welfare.

In retrospect, the Mühlens mission, its colonial character notwithstanding, represented a road not taken: that of systematic exploration of sanitary needs, under European guidance, but in the spirit of international and intercommunal cooperation, with local and European actors working together on apparently equal terms.

\section{The British Mandate: Competing Efforts to Shape Health Priorities}

\section{Wartime Health Policies: A Military Imperative}

World War I put a stop to this convergence. The International Sanitary Administration, the Pasteur Institute of Jerusalem, ${ }^{61}$ and the Jewish Health Bureau ${ }^{62}$ continued working, as did German and Austrian health foundations. Yet within Jerusalem, a garrison town and the first medical center behind the Sinai front, all efforts converged towards protecting the health of the troops from cholera and typhus. ${ }^{63}$ On the other side of the frontline, British military medicine had similar goals. Vulnerability to malaria was greater, but the British medical infrastructure was steadier: it kept Allenby's expeditionary corps healthy when the Ottoman troops collapsed militarily and medically in September $1918 .{ }^{64}$

Relief and healthcare were delegated to charities and humanitarian organizations with financial connections abroad, such as the Ottoman Red Crescent Society until $1917,{ }^{65}$ and the HMO, which stepped in after the British occupation and, in 1918, set up an American Zionist Medical Unit (AZMU) for emergency medical relief. ${ }^{66}$ By 1920-21, the Department of Health (DOH) had

\footnotetext{
6o "Alumni Association: Jerusalem Branch," Al-Kulliyeh 2, no. 3 (1911): 107-8.

61 Wulf, Jerusalem - Aleppo - Konstantinopel, 100-110.

62 "Wartime Health Work in Jerusalem," New York Times, December 28, 1919.

63 Oya Dağlar, War, Epidemics, and Medicine in the Late Ottoman Empire (1912-1918) (Haarlem: Sota, 2008).

64 Eran Dolev, Allenby's Military Medicine: Life and Death in World War I Palestine (London: I. B. Tauris, 2007).

65 Abigail Jacobson, From Empire to Empire: Jerusalem between Ottoman and British Rule (Syracuse: Syracuse University Press, 2011), 35 .

66 Jeffrey Gurock, American Zionism: Mission and Politics; American Jewish History, vol. 8 (London: Routledge, 2014).
} 
been established within the British Government of Palestine, ${ }^{67}$ but the delegation of healthcare to voluntary organizations remained.

\section{Establishing the Mandate's Healthcare Services: Conflicted Priorities}

Health policy-making in the early years of British rule in Palestine was characterized by the uncertainties surrounding the implementation of the Mandate and the transition from local-level administration to the state-in-becoming of Palestine. Jerusalem was now a power center and less a cause for sanitary concern at the municipal echelon.

Arab health priorities were determined by the rejection of the Balfour Declaration and the fear of the demographic consequences of Jewish immigration. In his diary on February 1, 1919, Jerusalem-born nationalist and pedagogue Khalil al-Sakakini called for Ellis Island-type sanitary controls on the border and the right of the Arab population of Palestine to choose who could immigrate. ${ }^{68}$ Without ever mentioning Zionism, Canaan betrayed similar demographic anxieties. In a speech on graduation day at the American University of Beirut in June 1923, he advocated pronatality measures as a foundation of national strength. ${ }^{69}$ His implicit argument was that Arab demography should be upheld in the face of Jewish immigration. He lay the onus of the responsibility on Arab women, whose lack of education, a pervasive concern in educated Palestinian Arab society, ${ }^{70}$ he blamed for the high rate of infantile mortality he witnessed among peasants in his Jerusalem clinic.

By contrast, Zionist experts appeared interested in the executive control of health policy-making and enforcement. Beyond the AzMU's emergency medical relief, experts took a structural perspective on health, stressing the strategic importance of the sanitary screening of newcomers in an immigration society. In 1920, a group of German Jewish physicians published a memorandum on the Duties and Organization of the Health Service in Palestine, drawing up recommendations on Palestine's health policy from a Zionist perspective. The memorandum distinguished four fields of operation: immigration control and quarantine, infectious diseases, lung diseases (primarily tuberculosis),

\footnotetext{
67 Simoni, A Healthy Nation, 48.

68 Khalil al-Sakakini, Yawmiyyat Khalil al-Sakakini [The diaries of Khalil al-Sakakini], vol. 3 (Beirut: Institute of Palestine Studies, 2004), 67.

69 Tawfik B. Canaan, "Al-Sihhah asas al-hayah al-qawmiyyah" [Health as the basis of national life], Al-Kulliyeh 9, no. 9 (1923): 391-95.

70 Ela Greenberg, Preparing the Mothers of Tomorrow: Education and Islam in Mandate Palestine (Austin: University of Texas Press, 2010).
} 
and healthcare centers. It advised the wholesale delegation of state functions, immigration control in particular, to the Zionist movement. ${ }^{71}$

\section{Health Administration: By Whom and for Whom?}

In spite of Zionist aspirations to take an ample role in Palestine's health administration, the Mandate system imposed constraints that prevented the concentration of power within one of the two communities. How did Palestine's dual healthcare system develop, if not out of an unequal political position? The main answer is that it reflected financial inequality, with the Kupat Holim affording Zionist healthcare institutions with state-of-the-art services while the Arab community was dependent on an impoverished DOH and voluntary institutions. ${ }^{72}$

Yet the financial issue was inseparable from the political one: who were the actors and beneficiaries of health policies? The question ran at several levels. Within the Zionist movement, the AZMU and the Kupat Holim fought over their agenda, social medicine, and the demands of insured workers, respectively. ${ }^{73}$

The views of the director of the AZMU, Dr. Isaac Rubinow, were based on principles of intercommunal assistance, but the organization, staffed solely by Jews, also found itself in conflict with the DOH. By 1922-23, the DOH was forced to make drastic budget cuts, and the main financial backer of Rubinow's organization, now rebranded as the HMO, was considering a redistribution of its funds between the HMO and the DOH. The ensuing conflict was as much about money as it was about the respective missions of the various health actors in Palestine, and indeed, the respective roles of representatives of the Jewish and Arab communities and of immigrants versus indigenous personnel, within these organizations. ${ }^{74}$

The redefinition of the respective roles of the government of Palestine and the Zionist organizations implied consideration of the bicommunal logic of the Mandate, which was to begin in July 1923. Following the terms of the Balfour Declaration, the mandatory government was required to facilitate the establishment of the Jewish National Home and to avoid any discrimination between the Jewish and Arab communities. This began with recruitment. Rubinow complained that the DOH cheated on its obligations vis-à-vis both communities and discriminated against Jewish immigrants:

\footnotetext{
71 Theodor Zlocisti et al., Aufgaben und Organisation des Sanitätsdienstes in Palästina (Berlin: Jüdischer Verlag, 1920), 9-12.

72 Sufian, "Healing Jerusalem," 129; Simoni, A Healthy Nation, 53-54.

73 Shvarts and Brown, "Kupat Holim," 28-46.

74 RAC, RF, FA802, 825, box 18: Rubinow to Seligsberg, Jerusalem, April 5, 1922.
} 
[Look] at the staff of the Public Health Department, for instance. Of some 45 or 50 physicians, only 4 or 5 are Jews, most of them Arab Jews. The one or two European Jews who have succeeded in obtaining positions have done so as a result of pressure and protests. Public health and sanitation in Palestine is entrusted by the government ... to Syrian, Greek and Armenian physicians, to anybody except Jews. ${ }^{75}$

Yet another consequence of the Mandate system was that policy was under international scrutiny, which induced a drive to pursue easily demonstrable results. In Belgian Ruanda-Urundi, the mandatory power targeted yaws as a disease for which an effective cure was liable to be found at a limited cost. ${ }^{76}$ In Palestine, the equivalent of yaws was malaria. Rubinow and Colonel Heron, the director of the $\mathrm{DOH}$, were quite sensitive to the international publicity given to their respective results, and accused each other of taking all the credit. ${ }^{77}$ Yet the AJDC was less sensitive to publicity than it was to the needs and development of Palestine's governmental institutions, and it consequently forced the HMO to scale down its operations.

\section{The First Health Week (1924): Manufacturing Consent}

There were various ways to publicize the success of mandatory health policies. One was to use telling indicators such as the infantile mortality rate, but this implied that these should be comparable across communities, or at least show a convergence between Jews and Arabs. Infantile mortality was a shared concern across the communities. It was a life-long preoccupation of Canaan, ${ }^{78}$ and a weapon for Rubinow to discredit Heron: the former wondered how the latter was able to boast the efficacy of his services, when the infantile mortality rates for the Arab population oscillated between 250 and 300 percent. ${ }^{79}$ The importance given to the infantile mortality rate reflected Arab and Jewish demographic anxieties, but the indicator was also considered the synthetic health indicator par excellence and the signifier of the Mandate's success. Speaking about African mandates in June 1925, William Rappard, a member of

\footnotetext{
75 Ibid.

76 Anne Cornet, Politiques de santé et contrôle social au Rwanda, 1920-1940 (Paris: Karthala, 2011). RAC, RF, FA802, 825, box 18: Alfred E. Cohn, "Final report and contract, ca. 1922."

78 Bourmaud, "'A Son of the Country," 118-19. RAC, RF, FA802, 825, box 18: Rubinow to Seligsberg, Jerusalem, April 5, 1922.
} 
the Permanent Mandates Commission, took vital statistics as the yardstick of the success of the mandates to improve the life of their population. ${ }^{80}$

Another way to show the success of health policies was to use attendance figures at awareness campaigns. The most popular event of this kind was the Health Week, organized for the first time in November 1924, under the guidance of the HMO and DOH, with the support of Jewish and Arab physicians and medias. According to various assessments, it attracted 6,000, ${ }^{81} 34,000,{ }^{82}$ and even up to 51,000 people in an official report, ${ }^{83}$ which is as good a proof as any of the importance given to demonstrating the event's popular success, and to a tendency to inflate figures to that end.

The Health Week, centered on a health exhibition at the Moscoviyyeh compound in Jerusalem, focused on health education, infantile mortality, and the dangers of malaria. Early on, Arab representatives had suggested active antimalaria propaganda among the Arab population to the mandatory government, ${ }^{84}$ especially as police enforcement of forcible antimalaria measures, such as throwing over water tanks, was becoming deeply unpopular. ${ }^{85}$ The Health Week, with posters of mosquitoes and displays on malaria prevention, attempted to manufacture Arab consent for prioritizing to antimalaria campaigns by displaying a less intrusive approach.

\section{Conclusion: Towards Differentialism}

Successful efforts to publicize health policies and antimalaria campaigns in particular, such as the Health Week, show that in the increasingly dual society of Jerusalem, an approach to health policy through health needs was not incompatible with a perception of different needs between the communities. Over time, this differentiation would allow a gap to grow between Jewish and Arab healthcare, but at the beginning of the 1920s, it seemed like the

8o Quoted in Philippe Bourmaud, "Les faux-semblants d'une politique internationale: la Société des Nations et la lutte contre l'alcoolisme dans les mandats (1919-1930)," in "Re-reading Mandate History through a Health Policy Lens," ed. Philippe Bourmaud, special issue, Canadian Bulletin of Medical History 30, no. 2 (2013).

81 Simmons, Hadassah, 70.

82 Sufian, "Healing Jerusalem," 142.

83 RAC, RF, FA115, 825, 2, box 61: Paul S. Carley, "Health Week in Palestine," 1924.

84 Library of the London School for Hygiene and Tropical Medicine, Government of Palestine, Proceedings of the first session of the Antimalarial Advisory Commission of the Department of Health, October 28, 1920.

85 See n. 37 . 
logical result of the coexistence of an indigenous and an immigrant population. Moreover, differences in healthcare provision and in health indicators created an opportunity for the inhabitants to make political demands, prolonging a Jerusalemite tradition of playing on communal differences to obtain funds. Yet with the budget cuts imposed on the DOH, this logic came to an end.

The communal character of sanitary data, inherited from the Ottoman period, was already obsolete by 1914, as epidemiological data circulated and started to be compared. Yet the mechanism of the Mandate, facilitating the development of one of the two national communities in Palestine, but prohibiting discrimination between Jews and Arabs, drew public attention to the gaps in the statistics. In the face of this, health policy makers had to organize intercommunal events to manufacture consent for their public health priorities and to give all Jerusalemites a sense of sharing the same city, both with its hazards and its growing, inclusive institutions.

This divergence was related to the uneven biological effects of certain diseases such as malaria on Jews and Arabs, but since awareness campaigns on the issue proved successful, divergences can largely be explained by financial and institutional differences. As the sanitary attention given to Jerusalem in the nineteenth century receded behind the city's new role as an administrative capital, the significance given to denominational differences in the city's social fabric from an epidemiological point of view declined. Immigration induced new urban sanitary scares, but with the development of the healthcare and health policies that immigration brought on, new forms of belonging - as an Arab or a Jew and as an urban dweller - also came into being. 